\title{
Rapid Lava Sand Filtration for Decentralized Produced Water Treatment System in Old Oil Well Wonocolo
}

\author{
Ekha Yogafanny ${ }^{1^{*}}$, Ayu Utami ${ }^{1}$, Kristiati E.A. ${ }^{2}$, Wibiana W. Nandari ${ }^{3}$ \\ ${ }^{1}$ Department of Environmental Engineering, Universitas Pembangunan Nasional Veteran Yogyakarta, INDONESIA \\ ${ }^{2}$ Department of Petroleum Engineering, Universitas Pembangunan Nasional Veteran Yogyakarta, INDONESIA \\ ${ }^{3}$ Department of Chemical Engineering, Universitas Pembangunan Nasional Veteran Yogyakarta, INDONESIA \\ *Corresponding author: ekha.yogafanny@upnyk.ac.id
}

SUBMITTED 25 February 2019 REVISED 18 March 2019 ACCEPTED 25 April 2019

\begin{abstract}
The Cepu Block Oil Field has been traditionally extracted since 2008 by the local community in Wonocolo. The oil well-produced gas and fluids consisted of crude oil and produced water. This oil production activity discharges high amounts of produced water. The fluids have been settled down in the sedimentation tank to gain the crude oil optimally. The remaining fluid called produced water has been discharged to the surface towards the river without any further treatment. This activity led to the deterioration of environmental quality. This study aimed to analyze the performance of produced water treatment by rapid sand filtration by measuring the degree of turbidity removal under the specific condition on a laboratory scale using lava sand. The sedimentation was conducted in 3 hours of retention time following the real field condition of the oil production process by community in one sample well. The rapid sand filtration was conducted by a fixed bed column method with $0.2 \mathrm{~cm}$ of grain size. The sedimentation process followed by the rapid sand filtration in produced water treatment yielded the high efficiency of turbidity removal reaching $98.65 \%$. The rapid sand filter also worked excellently in turbidity removal attaining $96.48 \%$ of efficiency. These results confirmed that the sedimentation already done by the community followed by the rapid sand filtration is promising decentralized technology to be applied in a remote area such as Old Oil Wells Wonocolo regarding turbidity removal.
\end{abstract}

KEYWORDS Produced Water; Decentralized System; Rapid Sand Filtration

(c) The Author(s) 2018. This article is distributed under a Creative Commons Attribution-ShareAlike 4.0 International license.

\section{INTRODUCTION}

The Oil and Gas industry consists of two major sectors, i.e. upstream and downstream sector. The upstream sector includes exploration and production/ exploitation/ extraction (Igunnu and Chen, 2012), while the downstream sector involves refinery as well as storage, distribution/ transportation, and marketing of the products (Kristiati, 2010; Amponsah and Opei, 2014). The wastewater generated from oil production/ exploitation/ extraction activities (upstream sector) is called produced water that is differentiated by so-called wastewater associated with oil refinery activities in the downstream sector, as it is shown in Figure 1. Naturally, a certain amount of water sits in the porous reservoir media together with hydrocarbon and gas. It is known as the formation of water. Produced water is categorized as a form of water which is trapped in the reservoir and other sources of water (additional water injection to maintain hydraulic pressure or enhanced oil recovery) extracted or pumped to the surface together with crude oil during the oil and gas production activities (Arthur, Langhus and Patel, 2005; Fakhru'l-Razi et al., 2009; Jiménez et al., 2018).
The complexity of produced water composition depends on the geographic location of the oil field, geological formation, and the extraction method. The produced water from natural gas production is ten times more toxic than that from the oil production, but the volume of produced water discharge from natural gas production is much lower (Jiménez et al., 2018).

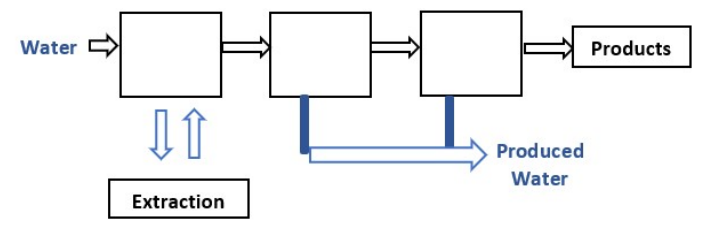

(a)

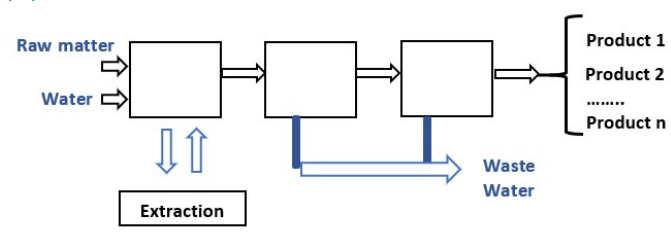

(b)

Figure 1. (a) Produced water from upstream activities, (b) Wastewater from downstream activities (Jiménez et al., 2018). 
The volume of produced water is relatively high for more than $80 \%$ of liquid pumped to the surface in potential fields and as high as $95 \%$ in aging or old oil fields (Igunnu and Chen, 2012). The major group's constituents of produced water are as follows:

a) Salts (expressed as salinity, total dissolved solid (TDS), or electrical conductivity)

b) Oil and Grease $(\mathrm{O} \& \mathrm{G})$

c) BTEX (benzene, toluene, ethylbenzene, and xylenes)

d) PAHs (polyaromatic hydrocarbons)

e) Organic acids

f) Phenol

g) Natural inorganic and organic compounds (e.g. chemicals that cause hardness and scaling such as calcium, magnesium, sulfates, and barium)

h) The chemical additive used during the drilling process that may have toxic properties (Fakhru'lRazi et al., 2009; Jiménez et al., 2018).
The history of the exploration of oil fields in Indonesia has been started since 1879, when Dutch Company, Dordsche Petroleum Maatschappij (DPM) discovered and exploited oil in Ledok Field in Cepu, Central Java (Kristiati, 2010). Once deemed uneconomical, the oil field was abandoned, and since 2008 this aging/ old oil wells in The Cepu Block were extracted traditionally by the community in Wonocolo. Since the old oil wells were extracted traditionally by local people, these activities have not been equipped by produced water treatment process The Cepu Block Oil Field Wonocolo is one of the wellknown aging or old oil field in Indonesia. Jati (2013) found that oil production activities in Wonocolo had a negative impact on the environment (land and surface water) as shown in Figure 2. However, this activity has been providing job opportunity and income for local communities.

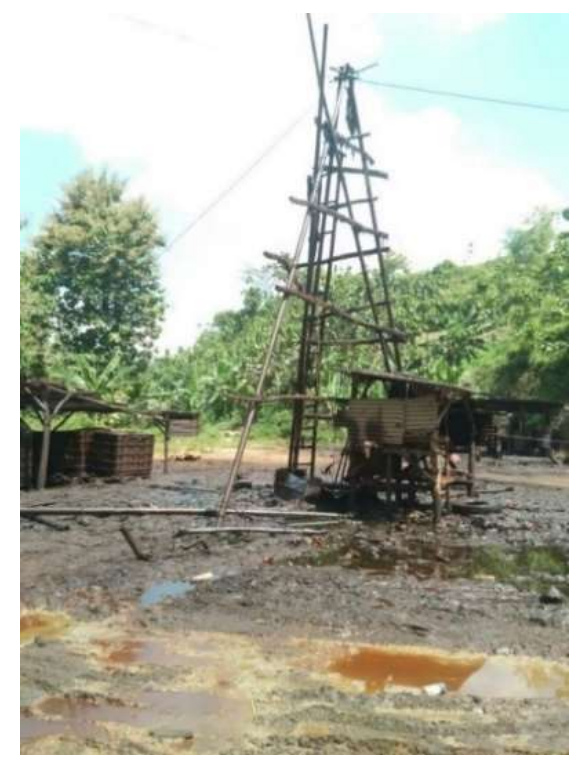

(a)

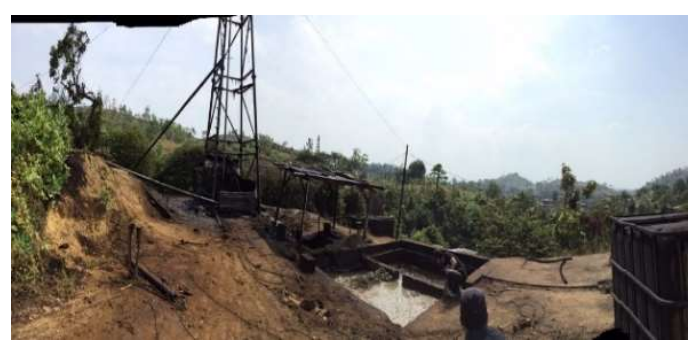

(b)

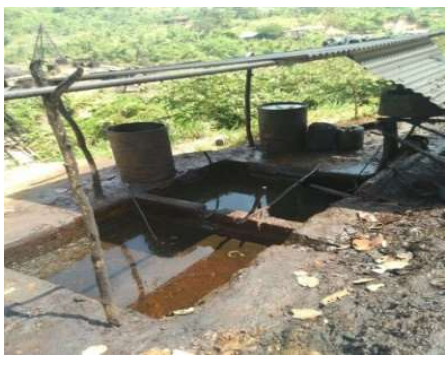

(c)

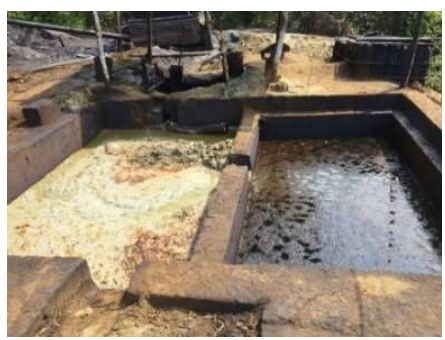

(d)

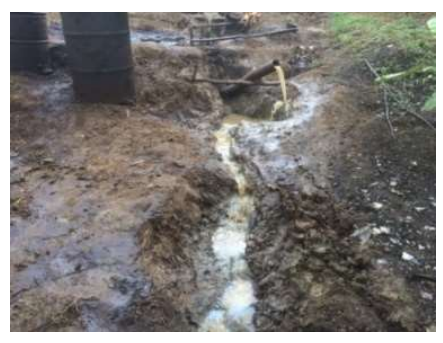

(e)

Figure 2. (a) Soil contamination in Oil Field Wonocolo, (b) Area of oil production, (c) sedimentation tank, (d) oil sludge deposition in the sedimentation tank, (e) produced water discharge to the environment after the sedimentation tank 
Recently, the produced water was discharged to the environment which then flowed to the small river crossed the oil field. The produced water from the sample well has a high turbidity concentration, i.e. 105 NTU. Not only the turbidity concentration but also the total dissolved solids (TDS) of produced water was high, i.e. $>10.000 \mathrm{mg} / \mathrm{l}$. Since the concentration of these two parameters was higher than the Indonesia Regulation (PP RI No. 82 the Year 2001 on Water Quality Management and Water Pollution Control), the produced water needs to be treated before its disposal. The treated water will be discharged to the river that was usually used for aquaculture and agriculture. This river is a tributary of Bengawan Solo River. The intended water quality is reaching the third class (for aquaculture) mentioned in PP RI No. 82 the Year 2001. In this class, the turbidity should be less than $25 \mathrm{NTU}$ and TDS less than $1000 \mathrm{mg} / \mathrm{l}$.

In old oil wells Wonocolo, the sedimentation tank is already installed near the oil well. This tank was built to allow the fluids extracted from the reservoir settling down for some hours (minimum 3 hours) to gain the crude oil optimally by the oil-water separation process. The crude oil that floats on the surface is taken manually using a water dipper. The remaining fluid, the produced water, is discharged into the environment through the pipe from the bottom of the tank. The illustration of the oil production process in old oil wells Wonocolo can be seen in Figure 3.

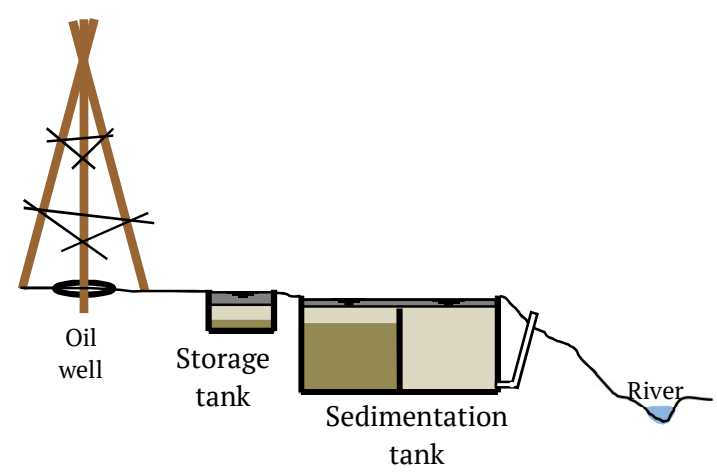

Figure 3. Illustration of the oil production process in old oil wells Wonocolo

The traditional process of oil production and the unskilled workers in the oil field Wonocolo lead to the deterioration of environmental quality regarding to no produced water treatment during the operation. The conventional produced water treatment is deemed as an impossible process conducted by the local community in terms of high investment, operational cost, and additional chemicals. The treatment process of produced water differs by the intended disposal method of the treated water. The disposal methods of produced water are environmental discharge, re-injection for pressure maintenance, and reuse for irrigation, livestock watering, aquifer storage, industrial process water (Jiménez et al., 2018). The common treatment techniques are physical treatment (adsorption, cyclones, enhanced floatation), biological treatment, membrane treatment (polymeric membranes, inorganic membranes, microfiltration/ ultrafiltration, nanofiltration and reverse osmosis), thermal technologies (evaporation, multistage flash, multieffect distillation, etc), and chemical treatment (ion exchange, advanced oxidation process, chemical precipitation, etc). These kinds of technologies are usually combined one to each other to reach the intended treated water quality and to sustain the equipment used in the treatment process (Jiménez et al., 2018).

The wastewater treatment system consists of three basic components, i.e. wastewater collection, wastewater treatment, and treated wastewater disposal. The first component is very important in centralized systems but costs more than $60 \%$ of the total budget in the wastewater management system (Zaharia, 2017). Based on the geographical condition of old oil field Wonocolo, the lack of funding as well as skill and knowledge, and indigenous local wisdom, it is worth to consider the decentralized produced water treatment in each oil well or adjacent oil wells. The decentralized system of produced water treatment allows the worker to individually collect the produced water from the already built sedimentation tank and then treat and dispose or reuse onsite the treated produced water. Therefore, this system promises a possible treatment system that more sensible from an ecological and economical point of view without the need to construct expensive sewer system. Best available technology also has to be considered in produced water treatment regarding to the need for simple technology, user-friendly, and availability of materials needed during the operation.

Filtration is a process where the water percolates through the filter media. Sand is the major filtering media used in water treatment by rapid or slow sand filtration. Its excellent performance in reducing suspended solid in the wastewater/ water made it becomes the major part of water treatment. Rapid sand filtration is commonly used in tertiary treatment after the coagulation and flocculation process 
(Schultz, 1990; Hani et al., 2018). Rapid sand filtration is less expensive than any other water treatment process in terms of material and no chemical used during the process. In term of the availability of sand and the less skill needed to operate the rapid sand filter, the rapid lava sand filtration that will be operating right after the sedimentation process is proposed to be further investigated and analyzed in terms of produced water treatment to remove turbidity and TDS.

There are many studies related to produced water treatment from a potential oil field that commonly has a higher concentration of TDS than an aging/ old oil field. Since those produced water treatments have been observed and are expected to be applied in the Oil and Gas Companies, which usually has a good commitment to environmental protection, reasonable investment, and operational costs are not the main problems as long as those remain effective and efficient. This study is considered challenging in this group of interest because the technology used in this produced water treatment is determined under special condition such as without chemicals and electricity, restricted access of oil field, not too high concentration of TDS due to the ageing/ old oil field, low knowledge and self awareness of workers toward environmental protection, geographical/ geomorphological condition of oil fields, traditional method of oil extraction, etc.

This study was aimed to analyze the performance of produced water treatment by rapid lava sand filtration by investigated the degree of turbidity and dissolved solids (TDS) removal under the specific condition. The results of this study were expected to be considered as the alternative technology of produced water treatment to be installed right after the sedimentation tank in the remote area of old oil field Wonocolo without any chemical added during the treatment.

\section{METHODS}

There were two steps in produced water treatment conducted by this research in laboratory scale, i.e. sedimentation and rapid sand filtration. The sedimentation process was conducted in three hours and followed by the rapid sand filtration in laboratory scale. Three hours of retention time in laboratory scale sedimentation process was determined based on the real condition of oil production in old oil wells Wonocolo. The fluids need at least three hours to settle down in the sedimentation tank. The dimension of sedimentation tank in laboratory scale was $50 \mathrm{~cm}$ of length, $30 \mathrm{~cm}$ of width, and $40 \mathrm{~cm}$ of height. The concentration of turbidity was measured both in the influent and effluent. The effectiveness of turbidity removal was evaluated from the difference between influent and effluent concentration.

The rapid sand filtration was conducted based on a fixed-bed column filter. The material used in this experiment was derived from lava sand with a grain size of $0.2 \mathrm{~cm}$. The lava sand was used in this experiment due to the research findings by Yogafanny and Maryono (2011) and Yogafanny, Fuchs and Obst (2014) found the lava sand performed better that river sand due to the grain shape. The grain shape of lava sand is more angular than the river sand. The filtration process was conducted in a fixed-bed column method that has a square cross-section $(5 \mathrm{~cm}$ $\mathrm{x} 5 \mathrm{~cm}$ ) and $120 \mathrm{~cm}$ of height. This filtration column was made from glass to be easily monitored what is occurring inside the column. The filter media was arranged in the column. It consisted of $50 \mathrm{~cm}$ height of sand, $10 \mathrm{~cm}$ height of gravel as a supporting layer in the bottom, and $5 \mathrm{~cm}$ height of gravel as protection layer above the sand. By adding the supporting layer in the bottom, the small-sized sand did not pass when the water flows to the faucet. The general process of produced water treatment in laboratory scale is shown in Figure 4, and the design criteria of rapid sand filtration experiment are shown in Table 1.

The influent was produced water derived originally from one of the old oil wells in Wonocolo. The produced water was first stored in the sedimentation tank. The turbidity of produced water before and after the sedimentation process was measured by a turbidimeter. The difference between these turbidity concentrations was evaluated to attain the removal effectiveness of turbidity in produced water treatment. After 3 hours sedimentation, the effluent of this process was delivered to the rapid lava sand filter. The filtration experiment was run once a day in the laboratory for one week. The amount of sample used in this filter column was 4 liters for each time running. The intermittent filtration process was conducted in this experiment by considering the real operation process in old oil wells Wonocolo. The oil production process in old oil wells Wonocolo is not 24 hours a day; it could be only 6 hours of oil production every day. 
Table 1. Design criteria of rapid sand filter column

\begin{tabular}{ll}
\hline Specification & Rapid sand filter \\
\hline Filter column: & $120 \mathrm{~cm}$ \\
Height & $5 \mathrm{~cm} \mathrm{x} 5 \mathrm{~cm}$ \\
$\begin{array}{l}\text { Surface area (square) } \\
\text { Filter media: }\end{array}$ & Lava sand \\
$\begin{array}{l}\text { Type of sand } \\
\text { Grain size }\end{array}$ & $0.2 \mathrm{~cm}$ \\
$\begin{array}{l}\text { The thickness of filter media } \\
\text { The thickness of supporting }\end{array}$ & $50 \mathrm{~cm}$ \\
media (gravel) & $10 \mathrm{~cm}$ \\
$\begin{array}{l}\text { Total weight of sand } \\
\text { Operation mode: }\end{array}$ & 2100 gram \\
Volume of sample water & 4 liter \\
Hydraulic loading rate (HLR) & $4.32 \mathrm{~m} /$ hour \\
\hline
\end{tabular}

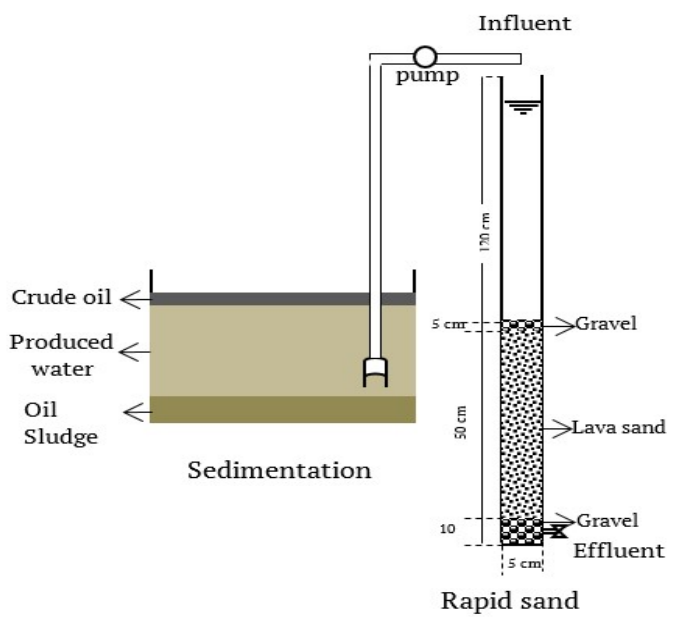

Figure 4. Experimental design of produced water treatment process in laboratory scale

The hydraulic loading rate (HLR) was adjusted at 4.32 $\mathrm{m} /$ hour. The operating mode used in this study was semi-batch that does not allow water flow in the inlet but allows the flow of treated water at the outlet. This

mode of operation was used because the assumption of the oil production process is intermittent; resulting in intermittent produced water flow. The turbidity concentration was measured before and after the sedimentation and rapid sand filtration. While the TDS concentration was measured before and after the filtration process, thus the differences between these concentrations were then evaluated with the formula that can be seen in Equation 1.

$$
\begin{aligned}
& \text { Turbidity } \\
& \text { removal } \\
& \text { efficiency }
\end{aligned}=\frac{\text { Inf.turbidity - Eff.turbidity }}{\text { Inf.turbidity }} \times 100 \%
$$$$
\text { (\%) }
$$

\section{RESULTS AND DISCUSSION}

In this study, the influent water was derived from the effluent of a storage tank applied in the old oil field Wonocolo. The turbidity concentration of influent water was first measured by turbidimeter i.e. 105 NTU. This water then settled in the sedimentation tank for 3 hours. After this, the effluent water from the sedimentation tank was measured by turbidimeter that can be seen in Table 2 .

The sedimentation process in produced water treatment absolutely improved the whole produced water treatment process in this study. Sedimentation can reduce the turbidity in a various number of efficiency up to $81.5 \%$. The sedimentation process is usually used as a pretreatment of rapid sand filtration when the level of turbidity in the raw water is $10-20$ NTU (Asmadi and Kasjono, 2011). In this experiment, the investigation was done by filtering the produced water in rapid sand filter right after the sedimentation tank even though the turbidity of produced water was above 20 NTU. There was no chemical addition prior to and after the sedimentation process.

Table 2. Turbidity concentration and its removal efficiency by sedimentation and rapid sand filtration

\begin{tabular}{cccccccc}
\hline \multicolumn{7}{c}{ Run } & \multicolumn{7}{c}{ TURBIDITY } \\
\cline { 2 - 6 } day & $\begin{array}{c}\text { Influent } \\
(\mathrm{NTU})\end{array}$ & $\begin{array}{c}\text { Effluent } \\
(\mathrm{NTU})\end{array}$ & $\begin{array}{c}\text { Removal } \\
\text { Efficiency (\%) }\end{array}$ & $\begin{array}{c}\text { Influe } \\
\text { nt } \\
(\mathrm{NTU})\end{array}$ & $\begin{array}{c}\text { Effluent } \\
(\mathrm{NTU})\end{array}$ & $\begin{array}{c}\text { Removal } \\
\text { Efficiency } \\
(\%)\end{array}$ & $\begin{array}{c}\text { Total Removal } \\
\text { Efficiency (\%) } \\
\text { Sedimentation-RSF }\end{array}$ \\
\hline 1 & 105 & 40.37 & 61.55 & 40.37 & 1.42 & 96.48 & 98.65 \\
2 & 105 & 19.43 & 81.50 & 19.43 & 4.02 & 79.31 & 96.17 \\
3 & 105 & 31.71 & 69.80 & 31.71 & 4.98 & 84.30 & 95.26 \\
4 & 105 & 100 & 4.76 & 100 & 4.12 & 95.88 & 96.08 \\
5 & 105 & 44.12 & 57.98 & 44.12 & 5.68 & 87.13 & 94.59 \\
6 & 105 & 53.67 & 48.89 & 53.67 & 25.01 & 53.40 & 76.18 \\
7 & 105 & 56 & 46.67 & 56 & 22.78 & 59.32 & 78.30 \\
\hline
\end{tabular}


This sedimentation process was followed by rapid sand filtration under semi-batch operation in 4.32 $\mathrm{m}$ /hour. Turbidity removal efficiency for the whole process was measured from the influent water before the sedimentation process and the effluent water after the rapid sand filtration. Figure 5 shows the turbidity removal efficiency in terms of times of running day experiment for 7 days. The efficiency of turbidity removal ranged from $76.18 \%$ to $98.65 \%$. The highest removal efficiency was achieved on the 1st day of running. From Figure 5, it was apparent that the performance of this filter decreases gradually by the running time. However, this filter still can work properly due to the turbidity removal efficiency i.e. $76.18 \%$.

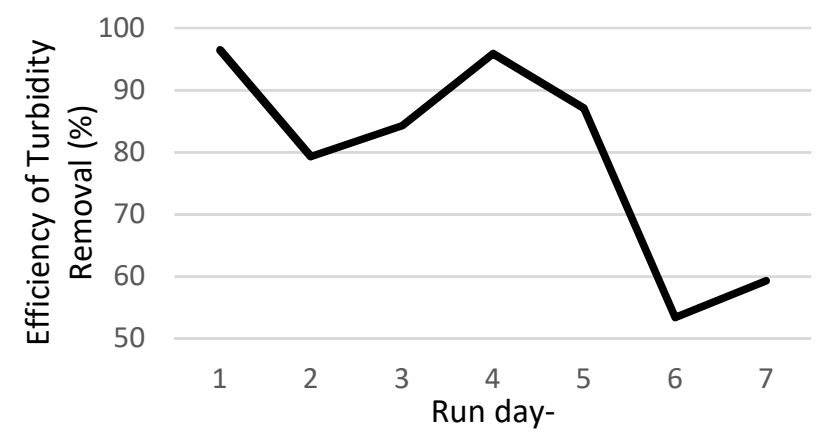

Figure 5. The turbidity removal efficiency of sedimentation followed by rapid sand filtration in produced water treatment

Figure 6 shows the concentration of turbidity before and after three hours of the sedimentation process. The effluent concentrations of turbidity during the experimental days were above the turbidity value allowed by the regulation (PP RI No 82 the Year 2010). It is proven that the sedimentation process without coagulation can not optimally remove the turbidity. So, the sedimentation process must be followed by further treatment such as rapid sand filtration.

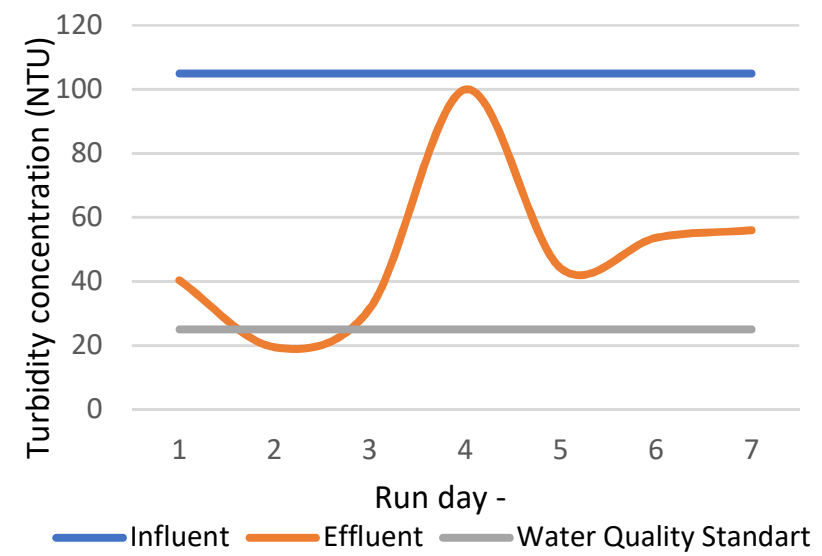

Figure 6. Turbidity concentration in the sedimentation process
Figure 7 depicted the efficiency of rapid sand filtration in removing turbidity. The concentration of turbidity in the inlet of rapid sand filtration was varying from 19.43 NTU up to 100 NTU. The removal efficiency was highly achieved by the filter in the $1^{\text {st }}$ day of running reaching $96.48 \%$. The performance of the filter under the hydraulic loading rate (HLR) of $4.32 \mathrm{~m} /$ hour in this study was excellent that also confirmed the study accomplished by Hani et al. (2018). Hani et al. (2018) found that the turbidity removal efficiency under lower HLR (4 m/hour) reached $87 \%$, higher than that of higher HLR (8 $\mathrm{m}$ /hour). The slower the hydraulic loading rate, the better is the performance of a filter in reducing turbidity.

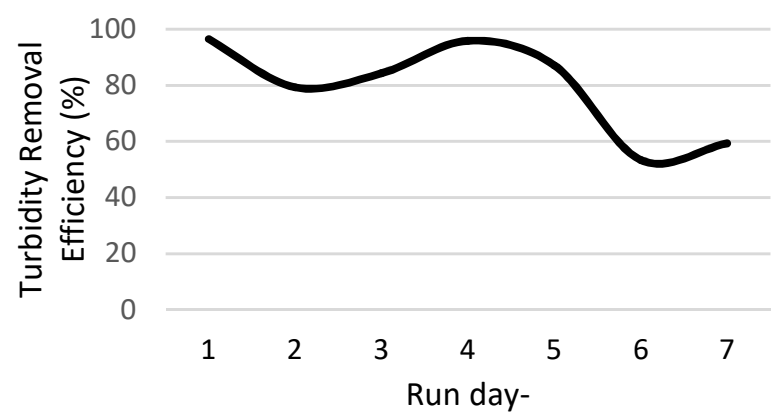

Figure 7. The turbidity removal efficiency of rapid sand filtration in produced water treatment

The graphic shown in Figure 8 obviously shows that the effluent turbidity reached the water quality standard ( $<25 \mathrm{NTU})$. The turbidity concentration in the effluent was $1.42 \mathrm{NTU} n$ the $1^{\text {st }}$ day of running and increased up to $22.78 \mathrm{NTU}$ at the 7 th day of running. The excellent removal of turbidity was due to the removal mechanisms in filter media i.e. sedimentation, adsorption, absorption, biological action, and straining. The modification of rapid sand filtration differed from conventional filtration and direct filtration. The use of the chemical was omitted during this process according to the intended application of this treatment system in Old Oil Wells Wonocolo. The results show that the rapid sand filtration using lava sand was reliable technology to be used in produced water treatment from the sedimentation process. 


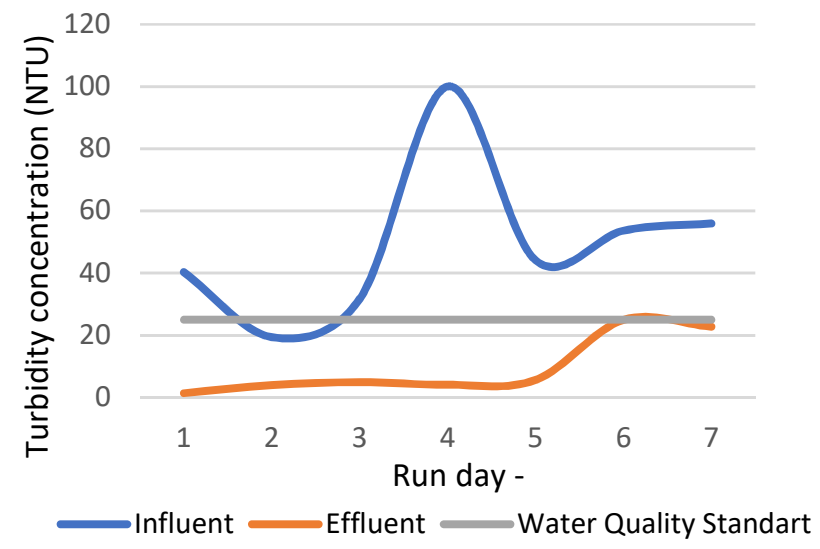

Figure 8. Turbidity concentration in rapid lava sand filtration

The good performance of a rapid sand filter in removing turbidity was caused by the straining and adsorption mechanism occurred in the filter bed (Schulz et al., 1992). Straining is the process of the suspended material trapping between the grains of filter media. Regarding the grain size of sand media and the filter column porosity, many suspended materials still can pass through the pores between the grains. The straining became the least important process especially in rapid sand filtration since the grain size was relatively bigger than that in slow sand filtration. The other removal mechanism called adsorption also worked in this rapid sand filtration. This removal process worked due to the sticking process of the particles on the sand surface. Since the particles were then accumulated on the surface and could not continue to flow downward through the sand media, these process then blocked the other particles to go further deeper in the sand. This process led to decrease the turbidity concentration in the outlet of the filter column hence increased the turbidity removal efficiency.

The other parameter that plays an essential role in rapid sand filtration is the hydraulic loading rate (HLR). HLR used in this experiment was $4.32 \mathrm{~m}$ /hour. This rate is relatively low compared to the ranges permitted i.e. 4 - $11 \mathrm{~m} /$ hour. (Hani et al. (2018) found that to gain higher turbidity removal, the adjustment between the sand depth and the HLR was crucial. The sand depth that was more suitable for HLR of 4 $\mathrm{m} /$ hour was $50 \mathrm{~cm}$. To increase the HLR to $8 \mathrm{~m} /$ hour, the depth of sand was also increased to $110 \mathrm{~cm}$. The optimum turbidity removal was achieved by the lower HLR ( $4 \mathrm{~m}$ /hour). These results confirm this recent study that the rapid sand filter operated under HLR of $4 \mathrm{~m} /$ hour resulted in high efficiency of turbidity removal reaching $96.48 \%$ that can be seen in Table 2 . However, the study related to the effect of various HLRs on filter performance in rapid sand filtration is important due to the wide ranges of HLR permitted by rapid sand filtration.

Figure 9 shows the performance of a rapid sand filter in reducing the dissolved solids (TDS) concentration in produced water. It can be seen from the graph that the removal efficiency fluctuated during the experiment. The removal efficiency of TDS was ranged from $-28 \%$ to $18 \%$. The performance of rapid sand filtration in TDS removal was in contrast to that in turbidity removal that shown in Table 3. It was confirmed the theory that the dissolved solid can be removed by the adsorption, ion exchange, or membrane filtration (Metcalf and Eddy, 2003). The possible removal mechanism of dissolved solid occurred in sand filtration was adsorption. However, this removal mechanism will only work under the specific condition such as typical filter media; low hydraulic loading rate thus longer contact time and small grain size. In this experiment, the rapid sand filter consisted of $0.2 \mathrm{~cm}$ of grain size of lava sand was adjusted in $4.32 \mathrm{~m} /$ hour which was relatively higher compared to the slow sand filter. This condition tended to decrease the performance of a rapid sand filter in reducing the dissolved solid in produced water thus represented in the fluctuation results shown in Figure 9. The high hydraulic loading rate tended to a shorter contact time between the sand media and the ions present in the produced water. Moreover, the filter media used in this experiment i.e. sand can not work as an ions exchanger or absorber. The commonly used ion exchange material is activated carbon, natural/ synthetic zeolite, and resin. The natural zeolite i.e. clinoptilolite can be used as ions exchanger by chemical and physical activation (Akdeniz, 1999). Clinoptilolite can be used as ions exchanger by chemical and physical activation (Akdeniz, 1999). 
Table 3. Turbidity concentration and its removal efficiency by sedimentation and rapid sand filtration

\begin{tabular}{lllllll}
\hline \multicolumn{6}{l}{ RAPID SAND FILTRATION (RSF) } \\
\hline \multirow{2}{*}{$\begin{array}{l}\text { Run } \\
\text { day }\end{array}$} & \begin{tabular}{l} 
Total Dissolved Solid (TDS) \\
\cline { 2 - 6 } \\
Influent
\end{tabular} & Effluent (mg/l) & $\begin{array}{l}\text { Removal } \\
\text { efficiency (\%) }\end{array}$ & $\begin{array}{l}\text { Influent } \\
\text { (NTU) }\end{array}$ & Effluent (NTU) & $\begin{array}{l}\text { Removal } \\
\text { efficiency (\%) }\end{array}$ \\
\hline & & & & & \\
1 & 2467 & 2367 & 4 & 40.37 & 1.42 & 96.48 \\
2 & 2460 & 2460 & 0 & 19.43 & 4.02 & 79.31 \\
3 & 2427 & 2473 & -2 & 31.71 & 4.98 & 84.30 \\
4 & 13613 & 11107 & 18 & 100 & 4.12 & 95.88 \\
5 & 10533 & 13480 & -28 & 44.12 & 5.68 & 87.13 \\
6 & 12673 & 12667 & 0 & 53.67 & 25.01 & 53.40 \\
7 & 13607 & 13567 & 0 & 56 & 22.78 & 59.32 \\
\hline
\end{tabular}

Generally, the results of this study showed that the rapid sand filtration as a combined technology along with sedimentation tank is very good in terms of turbidity removal.

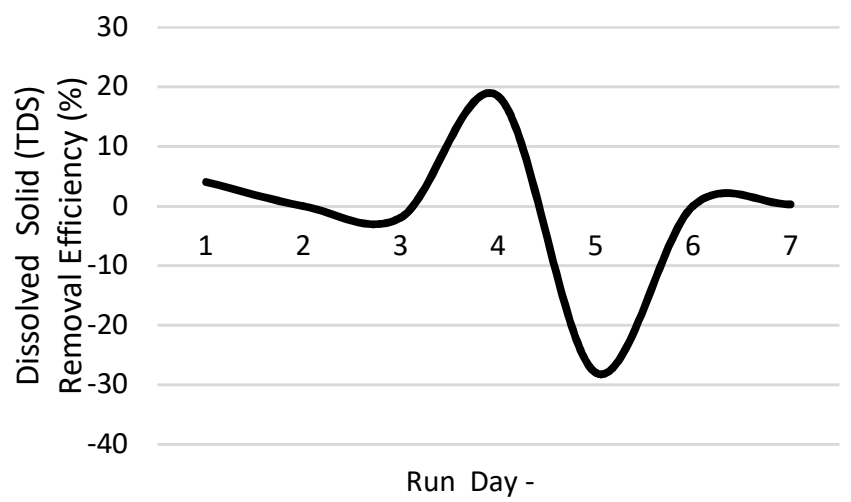

Figure 9. Dissolved solid (TDS) removal efficiency of rapid sand filtration in produced water treatment

Moreover, the rapid sand filter seems to be a promising technology to be applied as decentralized produced water treatment system especially in a remote area such as old oil wells Wonocolo regarding turbidity removal. However, backwashing time and methods need to be investigated. On the other hand, the performance of rapid sand filtration in reducing the TDS concentration was not good; hence the additional of other technology after rapid sand filtration is highly required. The granular media adsorption by zeolite and activated carbon seem worth to be further evaluated.

\section{CONCLUSIONS}

From this research, it can be concluded that the performance of produced water treatment using sedimentation followed by rapid sand filtration was generally good achieving $98.65 \%$ of turbidity removal efficiency. The rapid sand filtration had an excellent performance in terms of turbidity removal achieving $96.48 \%$ and gradually decreased to $53.40 \%$ at the end of the experiment. These results confirmed that the rapid sand filtration is a promising technology to be applied in the remote area such as Old Oil Wells Wonocolo regarding turbidity removal. It is even better for the decentralized produced water treatment system to have a longer sedimentation process as a pretreatment before rapid sand filtration.

\section{ACKNOWLEDGMENT}

This research is financially supported by the Institute of Research and Community Service (LPPM) Universitas Pembangunan Nasional (UPN) "Veteran" Yogyakarta, Indonesia under The Cluster Grant 2018. We also thank our colleagues and student assistance from the Environmental Engineering Department UPN Veteran Yogyakarta who supported this research. Last but not least, we dedicate this research to The Chairman of Petroleum Geoheritage Wonocolo Community, Mr. Suyitno (Pak Yossi) who gave his expertise and unconditional supports during the fieldworks in Wonocolo. He passed away in August 2018, and this paper is also to memorize his kindness.

\section{REFERENCES}

Akdeniz, Y. (1999) Cation Exhange in Zeolites, Structure Modification ny Using a Microwave Turkey. Izmir Institute of Technology. 
Amponsah, R. and Opei, F. K. (2014) 'Ghana's downstream petroleum sector: An assessment of key supply chain challenges and prospects for growth', International Journal of Petroleum and Oil Exploration Research, 1(1), pp. 1-7.

Arthur, J. D., Langhus, B. G. and Patel, C. (2005) 'Technical summary of oil \& gas produced water treatment technologies', All Consulting, LLC, Tulsa, $\mathrm{OK}$.

Asmadi, K. and Kasjono, H. S. (2011) 'Teknologi Pengolahan Air Minum', Gosyen Publishing. Pontianak, Hal, 11, pp. 25-27.

Fakhru'l-Razi, A. et al. (2009) 'Review of technologies for oil and gas produced water treatment', Journal of hazardous materials. Elsevier, 170(2-3), pp. 530-551.

Hani, M. et al. (2018) 'Effect of Operational Conditions on Performance of Deep sand Filter in Turbidity Removal', Trends in Technical and Scientific Research, 2(5), pp. 555-597.

Igunnu, E. T. and Chen, G. Z. (2012) 'Produced water treatment technologies', International Journal of LowCarbon Technologies. Oxford University Press, 9(3), pp. 157-177.

Jati, K. P. (2013) 'Persepsi Masyarakat Penambang Tradisional Terhadap Sumber Daya Minyak Bumi Di Kawasan Cepu', Geo-Image, 2(2).
Jiménez, S. et al. (2018) 'State of the art of produced water treatment', Chemosphere. Elsevier, 192, pp. 186208.

Kristiati, M. (2010) Minyak Bumi : Eksplorasi, Eksploitasi dan Produksi. Yogyakarta: PT. Citra Aji Pratama.

Metcalf and Eddy (2003) Wastewater engineering; treatment and reuse. McGraw-Hill.

Schultz, C. R. (1990) 'Water filtration technologies for developing countries', Environmental Sanitation Review, 46, pp. 37-78.

Schulz, C. R. et al. (1992) 'Surface water treatment for communities in developing countries'. Intermediate Technology Publications.

Yogafanny, E., Fuchs, S. and Obst, U. (2014) 'Study of slow sand filtration in removing total coliforms and $\mathrm{E}$. Coli', Jurnal Sains dan Teknologi Lingkungan. Islamic University of Indonesia, 6(2), pp. 107-116.

Yogafanny, E. and Maryono, A. (2011) Evaluating Bacteria Removal Potential by Slow Sand Filtration: Effects of Rhine and Lava Sand and Operation Mode. [Yogyakarta]: Universitas Gadjah Mada.

Zaharia, C. (2017) 'Decentralized wastewater treatment systems: Efficiency and its estimated impact against onsite natural water pollution status. A Romanian case study', Process Safety and Environmental Protection. Elsevier, 108, pp. 74-88. 
[This page is intentionally left blank] 